\section{JURNAL ABDIMAS

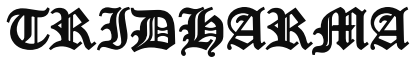

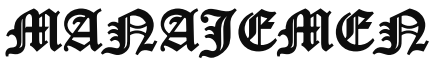

P-ISSN 2615-6849, E-ISSN 2716-070X

Jurnal ABDIMAS Vol.3,No.1,Desember 2021,Hal(1-14)

@ Prodi Manajemen Fakultas Ekonomi Universitas Pamulang

Email: abdimasjurnal.unpam@gmail.com Telp: (021) 741-2566

\title{
USAHA YANG MENJADIKAN PERUBAHAN DIMASA PANDEMI COVID-19
}

\author{
Fahmi Susanti $^{1}$, Adam Hafidz ${ }^{2}$, Sugeng Rahmadan ${ }^{3}$, Ichsan Abidin ${ }^{4}$, Alfian Legitya ${ }^{5}$, \\ Meilani Nimatul Maula ${ }^{6}$
}

1Dosen Prodi Manajemen Fakultas Ekonomi Universitas Pamulang ${ }^{2,3,4,5,6}$ Mahasiswa Manajemen Universitas Pamulang

Email : Dosen02024@unpamac.id Adamhafidz8585@gmail.com sugeng@globaljaya.com Isanabidin9@gmail.com Alfian89@gmail.com Mealaniruza99@gmail.com

\begin{abstract}
ABSTRAK
Pengabdian ini berjudul "Usaha yang menjadikan perubahan di masa pandemi Covid - 19" pada yayasan Hidayadullah pondok petir. Metode yang digunakan adalah dalam bentuk penyampaian materi dalam bentuk presentasi dan tanya jawab interaktif terkait pentingnya mengatur strategi dalam keuangan. Kesimpulan dari pengabdian ini adalah peserta penyuluhan sudah memahami tetapi belum maksimal, hanya mengetahui materi dasarnya saja mengenai mengatur atau menyimpan keuangan. Tujuan pengabdian ini adalah memberikan pelatihan dan pembenahan manajemen keuangan dan administasi pada yayasan Hidayatullah pondok petir. Kesimpulan dari pengabdian Melalui pelatihan ini, peserta berhasil memahami pentingnya pengelolaan keuangan dalam bidang usaha dan pentingnya pengelolaan yang efektif dan efisien menggunakan kasir online dasar untuk menunjang individu dalam mengatur keuangan pada bisnis yang di jalankannya..
\end{abstract}

\section{Kata kunci : Kewirausahaan, Manajemen}

\begin{abstract}
This service is entitled "Efforts that make a difference during the Covid-19 pandemic" at the Hidayadullah Pondok Lightning Foundation. The method used is in the form of delivering material in the form of presentations and interactive questions and answers related to the importance of managing strategies in finance

The conclusion of this service is that the counseling participants have understood but not maximized, only knowing the basic material about managing or saving finances. The purpose of this service is to provide training and improvement in financial management and administration at the Hidayatullah Pondok Lightning Foundation. Conclusion from service. Through this training, participants managed to understand the importance of financial management in the business sector and the importance of effective and efficient management using basic online cashiers to support individuals in managing finances in the businesses they run.
\end{abstract}

Keywords: Entrepreneurship, Management

\section{PENDAHULUAN}

Pengabdian dilakukan pada Yayasan Hidayatullah Pondok Petir Bojongsari Kota Depok. Analisis situasi dan latar belakang pengelolaan keuangan sebagai salah satu aspek penting bagi kemajuan sebuah usaha bisnis yang dapat dilakukan menggunakan praktik manajemen keuangan sederhana.

Kegiatan kewirausahaan atau bisa juga disebut UKM (Usaha Kecil Menengah) merupakan langkah yang strategis dalam upaya meningkatkan dan memperkuat aspek perekonomian. Dalam operasionalnya pelaku usaha menjalankan 


\section{JURNAL ABDIMAS

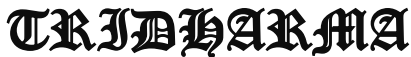 AtA:}

beberapa fungsi antara lain membantu konsumen dalam menyediakan berbagai produk dan jasa. Menjalankan fungsi pemecah maupun menambah nilai produk, secara keseluruhan pengelola bisnis membutuhkan implementasi fungsi-fungsi manajemen secara terintegrasi, baik fungsi keuangan, pemasaran, sumberdaya manusia, maupun operasional. Sehinga pelaku usaha dapat memahami secara penuh tentang lingkup bisnis usahanya secara

Strategis dalam mengembangkan manajemen bisnisnya.

Saat ini toko klontong dan pebisnis lainnya masih banyak menggunakan mesin kasir berplatform komputer. Komputer kasir mempunyai dua bagian yang sama-sama penting, yaitu hardware komputer kasir dan software program kasir. Hal yang mendasari kami membuat sistem ini adalah memanfaatkan smartphone sebagai platform untuk dijadikan sebagai mesin kasir, hanya perbedaanya dengan aplikasi kasir online berbasis smartphone ini dilengkapi dengan sms gateway, agar lebih mempermudah dalam memberikan notifikasi yang digunakan baik itu dalam informasi persediaan barang maupun sebagai

nota elektronik. Selain itu dengan adanya sistem ini swalayan atau toko-toko besar atupun kecil dengan mudah memantau perkembangan bisnisnya.

Pengelolaan keuangan para pebisnis tidak dapat dipandang mudah tetapmembutuhkan, ketelitian, keakuratan, transparansi, akuntabel, efektif, dan efisien. Dengan mempertimbangkan latar belakang yang telah diutarakan diatas kami berinisiatif untuk membentuk pengabdian kepada masyarakat bagi para remaja yang berkeinginan bahkan sudah memiliki sebuah usaha yang sedang dijalankannnya melalui program penyuluhan materi :

\section{RUMUSAN MASALAH}

Berdasarkan hasil analisa terhadap situasi dan beberapa masalah yang dihadapi oleh pemilik usaha, maka permasalahan prioritas yang akan ditangani dalam kegiatan ini adalah sebagai berikut:

1. Memberikan pelatihan manajemen keuangan dan administasi .

2. Memberikan pembenahan manajemen keuangan dan administrasi .

\section{TUJUAN DAN MANFAAT}

Uraian justifikasi pengusul bersama mitra dalam menentukan persoalan prioritas yang disepakati untuk diselesaikan selama pelaksanaan program PKM, yaitu: Masalah Tidak Tersedianya Manajemen Keuangan yang Memadai pada Yayasan Hidayatullah Podok Petir. Untuk mengatasi masalah :

1. Maka dilakukanlah : Pelatihan dan bimbingan teknik mengenai pengelolaan manajemen yang baik sesuai dengan kebutuhan pengguna da

berdasarkan standar keuangan yang berlaku. Pelatihan ini dirancang secara khusus agar mudah dipahami oleh pengguna. Pemberian ilmu terkait dengan manajemen keuangan serta diberikan simulasi terkait dengan pembukuan yang dibutuhkan oleh Yayasan Hidayatullah Pondok Petir. Tujuannya adalah agar pebisnis yang masih remaja ini dapat menerapkan manajemen keuangan secara layak dan memadai sehingga proses pembukuan keuangan berjalan dengan baik dan dapat dipertanggungjawabkan.

Masalah kedua : Belum adanya sistem administratif yang baik pada Yayasan Hidayatullah Pondok Petir ini. Untuk mengatasi masalah kedua, maka dilakukanlah pembenahan administrasi pada mitra dengan cara memberikan pelatihan sesuai dengan standar yang berlaku dan memadai. Selain itu untuk mengatasi masalah ini dilakukan juga simulasi sederhana bagaimana cara mengarsipkan dokumen yang baik sehingga pada saat penelusuran dokumen dapat dilakukan dengan mudah dan dapat dipertanggungjawabkan dengan baik.

Hasil yang diharapkan. 


\section{JURNAL ABDIMAS

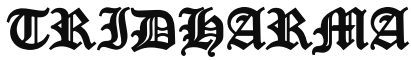

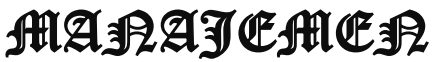

Adapun hasil yang diharapkan dari kegiatan ini adalah:

1. Kemahiran dalam pengelolaan atau manajemen keuangan pada Yayasan Hidayatullah Pondok Petir.

2. Keterampilan yang memadai dalam hal administrasi khususnya pengelolaan keuangan pada Yayasa Hidayatullah Pondok Petir.

3. Aplikasi yang memudahkan pebisnis untuk melakukan proses transaksi.

4. Aplikasi yang memudahkan pebisnis untuk mengelola persediaan barang dagangan.

5. Aplikasi digunakan untuk melihat laporan bulanan dimanapun dan kapanpun.

\section{METODE PELAKSANAAN}

Metode kegiatan yang digunakan adalah kita berkunjung dan bimbingan ke Yayasan Hidayatullah Pondok Petir

\section{LAPORAN PELAKSANAAN KEGIATAN PRA KEGIATAN}

\begin{abstract}
Persetujuan pelaksanaan pengabdian masyarakat pada kampus Universitas Pamulang dan YayasanHidayatullah

Pondok Petir guna membekali para peserta didik, dengantema Usaha Yang Me njadikan Perubahan Di Masa Pandemi Covid - 19.

Persiapan yang dilakukan adalah segala hal yang terkait dengan materi, bahan dan alat sesuai dengan tema secara
\end{abstract}

\section{MATERI PELATIHAN DAN DISKUSI PKM UASAHA YANG MENJADIKAN PERUBAHAN DIMASA PENDEMI COPID-19}

Prinsip ATM (Amati-Tiru-Modifikasi) Untuk Kesuksesan Bisnis yang Prinsip ATM atau Amati, Tiru dan Modifikasi adalah sebuah prinsip bisnis sudah populer. Bahkan, metode ini juga bisa diterapkan dalam hal lain. Jika Anda seorang pengusaha yang ingin selalu eksis walau ada banyak pesaing, maka ATM
Bojongsari Kota Depok. Pemaparan Materi pelatihan pengeloaan keuangan oleh pelaksana pengabdian masyarakat dengan tema pemaparan adalah hakekat manejemen keuangan di pebisnis kalangan remaja dan peran pengelolaan keuangan yang efektif dan efisien mendukung pengembangan usaha pada umumnya. Dengan metode pemaparan dalam melaksanakan manajemen keuangan secara umum. Di awal sesi pemateri memberikan beberapa pertanyaan sebagai bahan diskusi antara lain

1. Bagaimana pengelolaan keuangan di usaha para remaja yang sedang di jalankan saat ini?

2. Apakah Sudah baik ? Sudah sesuai rencana ? Sudah efisien ? Sudah Efektif?

3. Perlu atau pentingkah manajemen keuangan di pebisnis kalangan remaja

ini?

baik. Hasil persiapan tersebut dimaksudkan agar materi tersampaikan dengan mudah dimengerti serta dipahami oleh Yayasan Hidayatullah Pondok Petir.

\section{RENCANA \\ KEGIATAN}

PELAKSANAAN

Rencana pelaksanaan kegiatan adalah sebagai berikut :

Tempat : Yayasan Hidayatullah

Pondok Petir

Waktu : Pelaksanaan Kegiatan 21

Maret 2021

adalah sebuah prinsip atau strategi yang bisa Anda lakukan untuk tetap kreatif, berpikiran fresh serta menyediakan sesuatu yang lebih unik lagi. Tidak bisa dipungkiri jika ATM adalah cara yang tepat untuk mendapat banyak konsumen serta bertahan dari persaingan yang ada.

A. Mengamati
Maksudnya adalah Anda akan
mengamati jalannya bisnis yang 


\section{JURNAL ABDIMAS

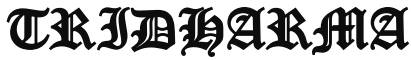 AtA}

P-ISSN 2615-6849, E-ISSN 2716-070X

Jurnal ABDIMAS Vol.3,No.1,Desember 2021,Hal(1-14)

@ Prodi Manajemen Fakultas Ekonomi Universitas Pamulang

Email: abdimasjurnal.unpam@ gmail.com Telp: (021) 741-2566 dijalankan oleh pesaing Anda. Mengamati bukan hanya melihat namun lebih tepat mempelajari. Mempelajari disini bisa dikaitkan dengan produk, startegi pemasaran dan lain-lain. Mengamati hampir sama dengan menganalisa serta menyimpulkan hasil pengamatan untuk dijadikan referensi di langkah selanjutnya, yakni Tiru. Mengamati seluk beluk bisnis pesaing adalah hal wajib yang harus dilakukan agar Anda tetap eksis di dunia bisnis.

B.

tiru

Usai proses pengamatan, maka hal berikutnya yang wajib Anda lakukan adalah dengan menirunya. Ingat, setelah memiliki pengetahuan yang cukup tentang suatu produk, maka langkah inilah yang dikatakan sebagai action. Memang terlihat mudah, yakni meniru saja. Namun, Anda harus paham tentang aspek yuridis terlebih lagi jika pesaing sudah memiliki hak paten atau daftar untuk produknya. Maka meniru tanpa keprofesionalismean bisa mengakibatkan fatal karena Anda akan dicap peniru, plagiat bahkan bisa dengan kata pencuri ide.

C.

\section{Modifikasi}

Memang benar jika Amati dan Tiru sudah cukup bagi Anda untuk tetap eksis di dunia bisnis. Hanya saja, akan terlihat membosankan bahkan cenderung monoton dan tidak kreatif jika Anda tidak melakukan sedikit modifikasi pada produk Anda. Anda harus tetap memberikan sentuhan yang berbeda pada produk Anda agar jauh dari kesan meniru. Karakter, sumber daya, gaya serta kondisi Anda harus memberikan warna dan sentuhan berbeda agar terlihat jauh dengan produk milik pesaing. Selain itu, sentuhan modifikasi akan memberikan kesan segar.
Teknik Penerapan Metode ATM Dengan Baik dan Benar

Strategi ini diyakini menjadi cara efektif untuk bisa menjadikan bisnis seorang pengusaha jadi lebih cepat berkembang dan bertumbuh. Karena dengan mengamati, meniru dan memodifikasi bisnis lain yang telah sukses, seorang pengusaha tak perlu lagi memikirkan ide bisnis terbaru yang membutuhkan waktu yang lama.

Lalu seperti apakah teknik menerapkan metode ATM yang baik dan benar dalam bisnis ini? Berikut 5 tips sukses penerapan motode ATM yang bisa Anda gunakan untuk bisnis Anda.

\section{Jangan Menjiplak}

Jika kita mau mengambil contoh negara yang seringkali menerapkan strategi ATM adalah Cina. Cina memang negara yang terkenal dengan produk-produk KW (tiruan)-nya. Meski banyak mendapat kritikan dari negara lain, negara tirai bambu ini tidak mau ambil pusing. Mereka selalu saja 'menutup telinga' dan membuat alibi bahwa permintaan yang datang mereka seringkali tidak bersamaan dengan permintaan kulitas produk.

Para pembeli mereka menurut mereka lebih mengutamakan harga yang murah daripada kualitas. Produk buatan Cina memang sudah terkenal dengan barang tiruannya yang sangat mirip dengan aslinya dengan harga yang miring.

Namun sayangnya yang seringkali dilakukan Cina bukannya memodifikasi, tapi menjiplak. Inilah yang membuat produk Cina tak memiliki kekuatan atau kehandalan dalam hal brand. Produk-produk buatan Cina ini malah sudah banyak mencap sebagai produk berkualitas rendah dan murahan. Yang dimaksud dalam metode ATM adalah memodifikasi, bukan meniru 100 persen alias menjiplak.

"Kamu bisa belajar dari pesaingmu, tetapi jangan pernah meniru. Ketika kamu meniru, kamu akan mati" Jack Ma, Founder Alibaba.com

2. Tidak Harus Dengan Ide Baru 


\section{JURNAL ABDIMAS

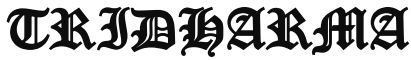

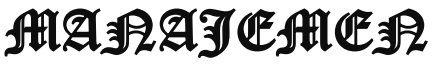

Masih banyak orang yang berpikiran bahwa untuk berwirausaha ia harus bisa membuat bisnisnya benar-benar merupakan bisnis baru agar tidak usahanya tak punya saingan. Ini adalah pemikiran yang salah. Untuk memulai bisnis tidak harus selalu dengan ide yang baru.

Memang bisa saja Anda menciptakan inovasi atau penemuan terbaru terhadap bisnis Anda, namun untuk membuat bisnis yang benarbenar baru tersebut Anda akan perlu membutukan waktu yang lama karena anda harus banyak memikirkan hal-hal yang baru mengenai ide bisnis baru Anda tersebut.

Dan satu hal lagi kemungkinan gagal pada bisnis dengan ide baru ini juga masih ada dan bahkan lebih besar daripada bisnis dengan yang sudah ada. Kegagalan ini disebabkan karena banyak hal yang masih belum tergambar oleh pasar atau pada bisnis baru itu sendiri.

"Modal tidak begitu penting dalam bisnis. Pengalaman tidak begitu penting. Anda bisa mendapatkan kedua hal ini. Yang penting adalah ide" $\sim$ Harvey Firestone, pendiri Firestone Tire \& Rubber Co

\section{Perbaiki Kekurangan Pasar}

Menjadi seorang modifikator bisnis itu artinya Anda harus mampu mengetahui permintaan pasar yang sudah terbentuk dan berusaha memperbaiki kekurangan tersebut. Dengan mengetahui kekurangan produk sebelumnya dengan kemudian Anda mampu memperbaikinya maka bisnis Anda akan memiliki kekuatan tersendiri yang unik dan berkarakter yang tidak dimiliki oleh orang lain. Inilah inti sebenarnya dari kata modifikasi dalam metode bisnis ATM.

\section{Misteri Rahasia Perusahaan}

Seringkali beberapa pengusaha memang memahami bahwa ketika mereka sudah melakukan teknik ATM dengan benar, maka bisnisnya akan sukses dengan cepat. Inilah yang salah kaprah, menerapkan metode ATM dalam bisnis itu hanyalah bagian dari meniru bagian luar bisnis yang ada. Akan masih banyak yang akan kita belum pahami dari bisnis yang ada seperti misalkan yang paling pasti adalah rahasia perusahaan.
Siapa pengusaha yang akan berani membocorkan rahasia perusahaannya? Inilah yang harus dipahami bersama oleh para pebisnis. Maka cobalah telusuri misteri perusahaan sukses sebisa mungkin untuk menjadikan bisnis metode ATM Anda berhasil dengan sukses.

\section{Perhatikan Proses}

Dalam bisnis apapun, proses memang selalu menjadi hal paling penting. Sebuah bisnis yang sudah berjalan dan sukses pasti sudah berbagai tahapan bisnis yang bernama proses. Kegagalan demi kegagalan dengan berbagai kisah pembelajaran didalamnya adalah hal yang telah dilewati bisnis yang sukses tersebut.

Untuk membuat bisnis berjalan sempurna, mereka telah melewati tahap atau proses trial and error yang berulang kali dan akhirnya menemukan hal yang terbaik yang kemudian dijadikan sistem baku. Proses inilah yang membentuk sebuah bisnis menjadi matang dan siap pakai, termasuk bisnis dengan metode ATM.

\section{PENUTUP}

Pelaksanaan kegiatan Pengabdian Kepada Masyarakat oleh Lembaga Penelitian dan Pengabdian Masyarakat (LPPM) Universitas Pamulang yang dilakukan oleh Mahasiswa/i program studi Manajemen telah berjalan dengan lancar dan mendapat sambutan hangat dari tempat pelaksanaan kegiatan ini yaitu Yayasan Hidayatullah Pondok Petir. Harapan kami dengan pengabdian ini dapat membuka wawasan dari Yayasan Hidayatullah Pondok Petir yang akan menghadapi era globalisasi. Materi yang kami berikan yaitu pendampingan dan pelatihan mengatur keuangan yang efektif dan efisien, sekaligus bahan kajian dan masukan bagi para remaja tersebut untuk dapat mengimplementasikannya dalam kehidupan sehari-hari, sehingga dapat membantu dan meningkatkan ekonomi dan keperibadian yang yang akan sangat bermanfaat dalam kehidupan mereka pada masa yang akan datang.

Dalam laporan kegiatan ini mungkin banyak kekurangan yang ada, untuk itu kami berharap masukan dan kritikan dalam rangka 


\section{JURNAL ABDIMAS

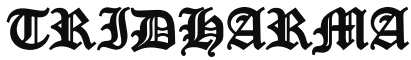

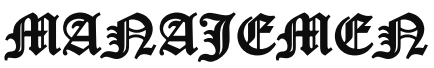

P-ISSN 2615-6849, E-ISSN 2716-070X

Jurnal ABDIMAS Vol.3,No.1,Desember 2021,Hal(1-14)

@Prodi Manajemen Fakultas Ekonomi Universitas Pamulang

Email: abdimasjurnal.unpam@ gmail.com Telp: (021) 741-2566 perbaikan untuk kegiatan-kegiatan pengabdian masyarakat di masa yang akan datang. Semoga kegiatan pengabdian masyarakat ini dapat bermanfaat bagi masyarakat sekitar lingkungan Universitas Pamulang. Kegiatan Pengabdian Kepada Masyarakat yang telah dilakukan Alhamdulillah berjalan lancar sesuai dengan rencana pelaksanaan kegiatan, meskipun terdapat sedikit kekurangan disana dan disini, namun kekurangan tersebut tidaklah substansial. Akhirnya, kami mengucapkan terima kasih kepada seluruh pihak yang telah mendukung kegiatan yang kami laksanakan dan kami mohon maaf apabila dalam laporan ini banyak ditemukan kekurangan.

\section{DAFTAR PUSTAKA}

Susanti, F., Jaswita, D. I., \& Mardiana, S. (2020). PENGEMBANGAN POTENSI EKONOMI KEWIRAUSAHAAN IBU RUMAH TANGGA DALAM MENINGKATKAN EKONOMI MASYARAKAT KELURAHAN CEMPAKA PUTIH CIPUTAT. Jurnal Lokabmas Kreatif: Loyalitas Kreatifitas Abdi Masyarakat Kreatif, 1(1), 89-95.

Pasaribu, V. L. D., Agrasadya, A., Shabrina, N., \& Krisnaldy, K. (2020). Menjadi Enterpreneur Muda Yang Memiliki Jiwa Leadership Untuk Menghadapi Masa Depan. Abdi Laksana: Jurnal Pengabdian Kepada Masyarakat, 1(1).

Pasaribu, V. L. D., Susanti, F., \& Hartuti, E. T. K. (2019). Memotivasi Siswa dan Siswi SMK Letris Indonesia di Dalam Menentukan Pilihan Untuk Melanjutkan Pendidikan Atau Bekerja Setelah Lulus Sekolah. Jurnal Pengabdian Dharma Laksana, 1(2), 161-172.

Pasaribu, V. L. D., Sulaiman, S., Sutiman, S., Thaharudin, T., \& Purnomo, B. Y. (2020). Pengenalan Letak Posyandu Terdekat Dikelurahan Pisangan Dengan Manajemen Pemasaran Revolusi 4.0 Untuk Meningkatkan Pengetahuan Masyarakat Letak Dan Fungsi Posyandu Terdekat Pada Kelurahan Pisangan. Dedikasi Pkm, 1(1), 105-110.

Pasaribu, V. L. D., Oktrima, B., Prabowo, B., Arianto, N., \& Haryoko, U. B. (2020). Progam Pendampingan Dan Penyelenggaraan Pendidikan Anak Pada Usia Dini Terhadap Prestasi Belajar
Dilingkungan Rt 020 Rw 009. Kel Giri Peni. Kec Wates. Yogyakarta. Jurnal Lokabmas Kreatif, 1(1), 71-75.

Pasaribu, V. L. D., Jannah, M., Fazar, M., Putra, S. P., Monalisa, M., \& Sofa, M. (2021). MENINGKATKAN PRODUKTIVITAS USAHA DIMASA PANDEMI PADA IBU PKK RT 004/003 KELURAHAN SAWAH BARU CIPUTAT, TANGERANG SELATAN. Abdi Laksana: Jurnal Pengabdian Kepada Masyarakat, 2(2), 295-301.

Pasaribu, V. L. D., Yuniati, H. L., Pranata, R., Sembayu, R., Purba, S. M., \& Nurbayani, T. T. A. (2021). MANAJEMEN KEUANGAN UNTUK MENGHADAPI DAN BERTAHAN DI ERA COVID 19. Jurnal Abdimas Tri Dharma Manajemen, 2(2), 12-18.

Pasaribu, V. L. D., Dwiyatni, A., Sabina, C., Ridwan, M., Gunawan, D. D., \& Noviani, B. C. (2021). EVALUASI PENERAPAN 3M DIMASA PANDEMIC COVID 19. Jurnal Abdimas Tri Dharma Manajemen, 2(2), 54-60.

Pasaribu, V. L. D., Syafei, A. N., Farhan, A., Aufaizah, A., Irani, C., \& Firtiayani, S. R. (2021). PENGARUH DISPLIN PROTOKOL KESEHATAN TERHADAP PENCEGAHAN PENULARAN VIRUS COVID19. Jurnal Abdimas Tri Dharma Manajemen, 2(2), 91-98.

Pasaribu, V. L. D., Septiani, F., Rahayu, S., Lismiatun, L., Arief, M., Juanda, A., ... \& Rahim, R. (2021). Forecast Analysis of Gross Regional Domestic Product based on the Linear Regression Algorithm Technique.

Priadi, A., Pasaribu, V. L. D., Virby, S., Sairin, S., \& Wardani, W. G. (2020). Penguatan Ekonomi Kreatif Berbasis Sumber Daya Desa Dikelurahan Rempoa. Abdi Laksana: Jurnal Pengabdian Kepada Masyarakat, 1(3), 356-35

Pasaribu, V. L. D., Priadi, A., Anismadiyah, V., Rahayu, S., \& Maduningtias, L. (2021). PENYULUHAN KREATIF DAN INOVATIF MENINGKATKAN MUTU PRODUKSI UMKM DI DESA BELEGA KABUPATEN GIANYAR. Pro Bono Jurnal 


\section{JURNAL ABDIMAS

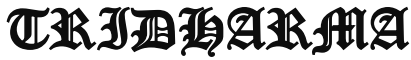 代A}

P-ISSN 2615-6849, E-ISSN 2716-070X

Jurnal ABDIMAS Vol.3,No.1,Desember 2021,Hal(1-14)

@Prodi Manajemen Fakultas Ekonomi Universitas Pamulang

Email: abdimasjurnal.unpam@gmail.com Telp: (021) 741-2566
Pengabdian

Masyarakat, 1(02).

Pasaribu, V. L. D. (2021). PELATIHAN BERBASIS ONLINE DI ERA COVID-19. Jurnal Abdimas Tri Dharma Manajemen, 2(3), 26-32.

Pasaribu, V. L. D., \& Setyowati, R. (2021).

ADAPTASI

KEHIDUPAN NEW NORMAL

PADA MASA PANDEMI

COVID-19 DIYAYASAN

PONDOK PESANTREN DAN

PANTI ASUHAN NURUL

IKHSAN KECAMATAN SETU,

KOTA

TANGERANG

SELATAN. Jurnal Lokabmas

Kreatif: Loyalitas Kreatifitas Abdi Masyarakat Kreatif, 2(2), 82-88.

Susanti, F., Ratnawati, W., \& ivan Jazwita, D. (2020). Literasi Digital Facebook dan Whatsapp terhadap Motivasi Belajar Generasi Milenial. Jurnal Lokabmas Kreatif: Loyalitas Kreatifitas Abdi Masyarakat Kreatif, 1(2), 35-40.
Susanti, F., Lisdawati, L., Andini, R., Setiawan, R., \& Ratnawati, W. (2020). Menanamkan Jiwa dan Semangat Kewirausahaan Persaingan Menghadapi di Era Globalisasi pada Guru dan Orangtua Murid Bimbingan Belajar Bimba Pamulang Tangerang Selatan. DEDIKASI PKM, 1(1), 95-100.

Nurwita, N., Susanti, F., Permada, D. N. R., \& Oktrima, B. (2020). DAMPAK BURUK PEMAKAIAN MEDIA SOSIAL TERHADAP SEMANGAT DAN CAPAIAN BELAJAR SISWA SMP ARRAISIYAH PAMULANG". Jurnal Abdimas Tri Dharma Manajemen, 1(1), 66-76.

Susanti, F., Lisdawati, L., Hulasoh, E., Malik, C. D., \& Fadillah, F. (2021). PELATIHAN DAN PEMBENAHAN MANAJEMEN KEUANGAN DAN ADMINISTRASI PADA YAYASAN NURUL IMAN Kelurahan Ciater Serpong Kota Tangerang Selatan. Pro Bono Jurnal Pengabdian Kepada Masyarakat, 1(01).

\section{Dokumentasi Kegiatan}

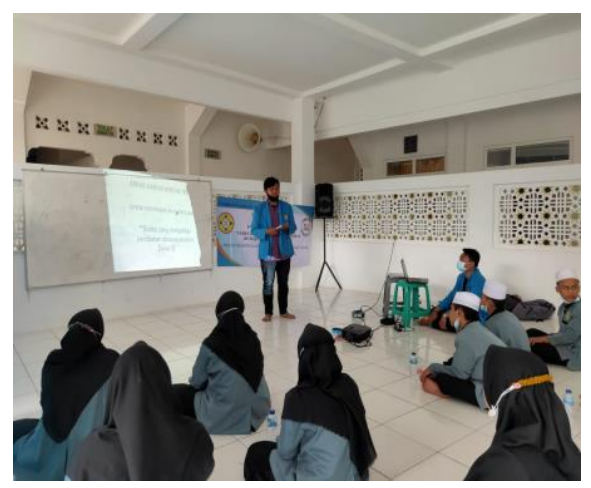

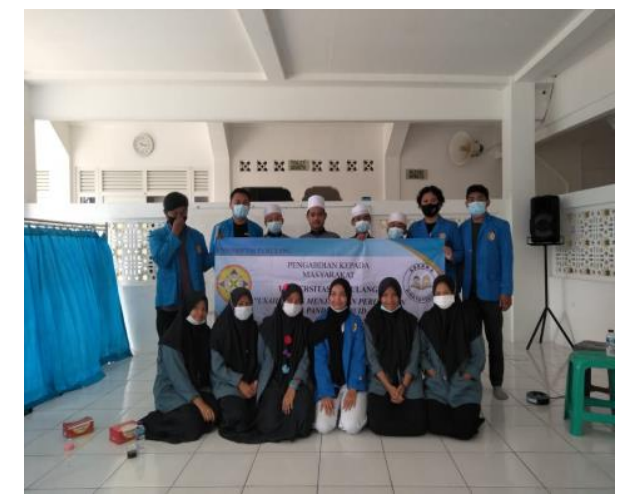

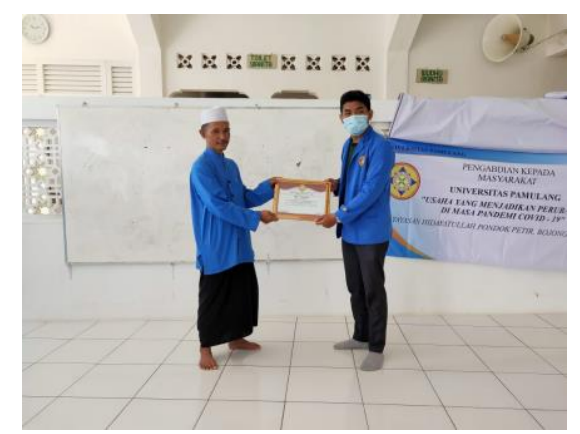

